Cellular Physiology
and Biochemistry and Biochemistry Poll 10.1159/000443067 2016

Accepted: January 12, 2016

This article is licensed under the Creative Commons Attribution-NonCommercial-NoDerivatives 4.0 International License (CC BY-NC-ND) (http://www.karger.com/Services/OpenAccessLicense). Usage and distribution for commercial purposes as well as any distribution of modified material requires written permission.
(C) 2016 The Author(s)

Original Paper

\title{
IL-10 Induces T Cell Exhaustion During Transplantation of Virus Infected Hearts
}

\author{
Asmae Gassa ${ }^{a, g}$ Fu Jian ${ }^{b}$ Halime Kalkavana,e Vikas Duhan ${ }^{a}$ Nadine Honke ${ }^{a}$ \\ Namir Shaabani ${ }^{a}$ Sarah-Kim Friedrich ${ }^{a}$ Sebastian Dolfff ${ }^{b, d}$ Thorsten Wahlers ${ }^{g}$ \\ Andreas Kribben $^{b}$ Cornelia Hardt ${ }^{a}$ Philipp A. Lang ${ }^{c, f}$ Oliver Witzke ${ }^{b, d}$ \\ Karl S. Lang ${ }^{\mathrm{a}, \mathrm{c}}$
}

aInstitute of Immunology, University Hospital Essen, University of Duisburg-Essen, Essen, ${ }^{\mathrm{b}}$ Department of Nephrology, University Hospital Essen, University of Duisburg-Essen, Essen, 'Department of Gastroenterology, Hepatology and Infectious Diseases, Heinrich-Heine-University of Düsseldorf,

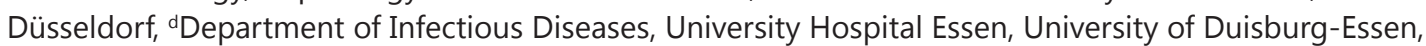
Essen, eDepartment of Medical Oncology, West German Cancer Centre, University of Duisburg-Essen, Essen, 'Department of Molecular Medicine II, Medical Faculty, Heinrich-Heine-University of Düsseldorf, Düsseldorf, ${ }^{9}$ Department of Cardiothoracic Surgery, Cologne University Heart Center, University of Cologne, Cologne, Germany

\section{Key Words}

LCMV • Heart transplantation • Rejection $\cdot \mathrm{T}$ cell exhaustion $・ I L-10 \cdot$ Mouse model

\begin{abstract}
Background/Aims: Unexpected transmissions of viral pathogens during solid organ transplantation (SOT) can result in severe, life-threatening diseases in transplant recipients. Immune activation contributes to disease onset. However mechanisms balancing the immune response against transmitted viral infection through organ transplantation remain unknown. Methods \& Results: Here we found, using lymphocytic choriomeningitis virus (LCMV), that transplantation of LCMV infected hearts led to exhaustion of virus specific CD8 ${ }^{+} \mathrm{T}$ cells, viral persistence in organs and survival of graft and recipient. Genetic depletion of Interleukin-10 $(I L-10)$ resulted in strong immune activation, graft dysfunction and death of mice, suggesting that $I L-10$ was a major regulator of $C D 8^{+} \mathrm{T}$ cell exhaustion during SOT. In the presence of memory $\mathrm{CD} 8^{+} \mathrm{T}$ cells, virus could be controlled. However sufficient antiviral immune response resulted in acute rejection of transplanted heart. Conclusion: We found that virus transmitted via SOT could not be controlled by naïve mice recipients due to $I L-10$ mediated $C D 8^{+} T$ cell exhaustion which thereby prevented immunopathology and graft failure whereas memory mice recipients were able to control the virus and induced graft failure.
\end{abstract}

\section{Introduction}

(C) 2016 The Author(s) Published by S. Karger AG, Basel

Heart transplantation is the therapy of choice for patients with heart insufficiency. So far, limited amount of available donor organs and the rejection of hearts after transplantation are major problems in heart transplantation [1-3].

A. Gassa, F. Jian and H. Kalkavan contributed equally to this work.

Karl S. Lang

KARGER
Institute for Immunology, University of Duisburg-Essen

Hufelandstr. 55, 45147, Essen, (Germany)

Tel. +49-201 723 4273, Fax +49-201 723 5410, E-Mail karlsebastian.lang@uk-essen.de 


\section{Cellular Physiology Cell Physiol Biochem 2016;38:1171-1181 \\ \begin{tabular}{l|l} 
and Biochemistry Published online: March 11, 2016 & $\begin{array}{l}\text { D } 2016 \text { The Author(s). Published by S. Karger AG, Basel } \\
\text { www.karger.com/cpb }\end{array}$
\end{tabular} \\ Gassa et al.: Donor Derived Viral Infection During Murine Heart Transplantation Induces T Cell Exhaustion}

The main reason for graft rejection is viral infection during heart transplantation. $40 \%$ of the heart rejections in humans are associated with infections $[4,5]$. Those infections are mainly herpes viruses. Considering viral infection in transplantation, we distinguish between reactivation of previous infections in donor or recipient and unexpected transmission of viral infections through organ transplantation which is defined as donor-derived viral infection. Even though, transmission of acute or latent infection to organ transplant recipient is approximately $0.2 \%$ of transplantation; once it occurs, it leads to significantly increased morbidity and mortality in recipients [6]. Expected viral infections detected by serological analysis in transplantation medicine are known for cytomegalovirus (CMV), Epstein-Barr virus (EBV) and hepatitis B virus (HBV) [7]. Special prophylaxis and infection management are preserved in this setting.

Of greater concern are unexpected viral infections transmitted via donor organs. Several reports of infectious diseases through SOT are published and estimated number of unreported cases has to be considered. Donor-derived viral infections include a growing number of pathogens such as hepatitis B and C, herpes viruses, human T-cell lymphotropic viruses (HTLV) 1 and 2, West Nile virus, Rabies, LCMV, polyomavirus, parvovirus B19 and many other viruses $[8,9]$. In most of such transmissions the mortality is high [10].

Detection of infectious disease in transplant donors is limited by technical means and by the short time period between death of donor and the use of donor organs. So, routinely evaluation of donors for infectious disease is determined by antibody detection. Nevertheless, a window of false negative detection for infectious disease exists. For example, the window for hepatitis $\mathrm{C}$ virus (HCV) to seroconversion is 30 to 70 days. Improvements have been done by nucleic acid testing (NAT), so that the time period could be reduced. But still, some infections remain undetected $[11,12]$.

$\mathrm{T}$ cells have emerged as a major threat in acute rejection after SOT [13]. Whether naïve or memory T cells get activated by transfer of viral infected hearts remains unclear. Further analysis has to be done in the field of transplantation medicine to understand the activation of immune cells by this route of infection. Mechanisms leading to exhaustion of T cells and in consequence to tolerance in transplantation medicine have to be investigated.

Here we transplanted hearts from LCMV carrier mice into naïve or memory C57BL/6 mice and analyzed proliferation of $\mathrm{CD}^{+} \mathrm{T}$ cells, viral clearance and syngeneic graft survival. We found that syngeneic heart transplantation (HTX) of LCMV carrier heart led to viral persistence in wild type (WT) mice, but also to syngeneic graft survival. Viral persistence and syngeneic graft survival in WT mice were due to $I L-10$ induced T cell exhaustion. In case of memory mice as recipient, $I L-10$ was not able to exhaust memory CD8 ${ }^{+} \mathrm{T}$ cells and virus could be controlled leading to syngeneic graft rejection. Transplantation of LCMV carrier heart in $I L-10$ deficient mice caused death due to immunopathology.

\section{Materials and Methods}

\section{Heterotopic Cardiac Transplantation}

Syngeneic heart transplant was vascularly anastomosed in an intraabdominal location using the technique described by Corry et al. [14, 15] as modified by Nagano et al. [16]. Graft ischemic time was typically 20 - 25 min and total operative time was 45 - 50 min with a success rate (beating hearts) of more than $90 \%$. Rejection of heart graft was not associated with death of recipients. The graft function was evaluated by palpation of the abdominal wall daily after operation. The function of the donor heart was assessed using a subjective score of 0 to 3 described by Corry et al. (zero for no beating; 0.5 for very weak beating; one for weak beating; two for moderate beating; three for full beating).

Mice

All mice used in this study were maintained on the C57BL/6 genetic background. Tcrb ${ }^{-}$mice are genetically engineered immune deficient mice which lack $\mathrm{T}$ cell receptor beta chain [17]. DEE mice are transgenic mice that express ubiquitously LCMV-GP under the $\mathrm{H}-2 \mathrm{k}$ promoter [18]. Tcrb\%, C57BL/6 (WT) 


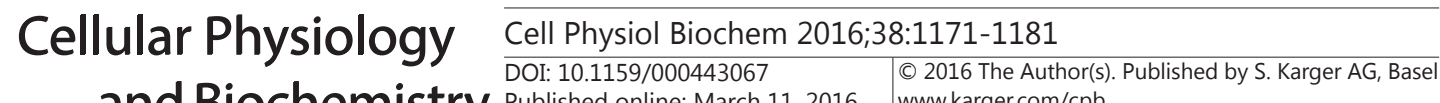

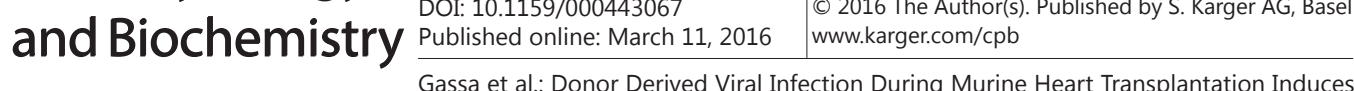 $T$ Cell Exhaustion}

and DEE mice were used as heart transplant donor. As recipient, we used C57BL/6 mice and $I L-10^{\circ /}$ mice, which lack the production of the immunoregulatory cytokine $I L-10$ [19]. At least eight-weeks-old male mice were used as recipients for all studies. All animals were housed in single ventilated cages. During survival experiments, the health status of mice was checked twice daily. Animal experiments were authorized by the Nordrhein Westfalen Landesamt für Natur, Umwelt und Verbraucherschutz (Recklinghausen, Germany), and in accordance with the German and Canadian law for animal protection.

Virus and plaque assay

LCMV strain WE was originally obtained from F. Lehmann-Grube (Heinrich Pette Institute, Hamburg, Germany) and was propagated in L929 cells. $\mathrm{Tcrb}^{-1}$ mice were infected intravenously with 2 x $10^{6} \mathrm{PFU}$ of LCMV-WE to generate carrier mice. For creation of memory mice, naïve C57BL/6 mice were infected intravenously with $200 \mathrm{PFU}$ of LCMV strain WE. Viral titers were measured in a plaque forming assay using MC57 cells as previously described [20].

CK-MB, Trop I, LDH and ALT

Biochemical analysis of creatinine-kinase MB (CK-MB), troponine I (Trop I), lactate dehydrogenase $(\mathrm{LDH})$ and alanine transferase (ALT) were done in sera by the central laboratory, University Hospital Essen, Germany.

\section{Flow cytometry}

Tetramers were provided by the National Institute of Health (NIH) Tetramer Facility. In short, 20 $\mu \mathrm{l}$ of blood was stained with allophycocyanin (APC)-labeled GP33 MHC class I tetramers (GP33/H-2Db) for 15 minutes at $37^{\circ} \mathrm{C}$. After incubation, the samples were stained with anti-CD8 peridinin-chlorophyllprotein-complex (PerCP; BD Biosciences, Franklin Lakes, NJ) for 30 minutes at $4^{\circ} \mathrm{C}$. Erythrocytes were then lysed using $1 \mathrm{ml}$ BD lysing solution (BD Biosciences); cells were washed with FACS buffer and analyzed in flow cytometer. Absolute numbers of GP33-specific CD8 ${ }^{+} \mathrm{T}$ cells were calculated from FACS analysis using fluorescing beads (BD Biosciences). For intracellular interferon gamma (IFN)- $\gamma$ staining, splenocytes or lymphocytes in blood were stimulated with GP33 in the presence of Brefeldin A. After 6 hours, cells were stained for CD8 for 30 minutes at $4^{\circ} \mathrm{C}$, fixed with $2 \%$ Formaldehyde for 10 minutes and permeabilized with $1 \%$ Saponin solution, and stained for IFN- $\gamma$ with anti-mouse IFN- $\gamma$ antibody (eBioscience) and analyzed in flow cytometry.

\section{IL-10 ELISA}

Enzyme linked immunosorbent assay (ELISA) has been performed by the Mouse $I L-10$ ELISA ReadySET-Go! ${ }^{\circledR}$ reagent kit using $20 \mu \mathrm{l}$ of plasma.

\section{Histologic analysis}

Histologic analysis of snap-frozen tissues were performed for immunohistochemistry with mouse monoclonal antibodies to LCMV nucleoprotein (made in house) and CD8 (BD Bioscience) and haematoxylin eosin staining (H\&E).

\section{Statistical analysis}

If not differently stated data are expressed as means and S.E.M. Student's t-test was used to detect statistically significant differences between groups. Significant differences between several groups were detected by two-way analysis of variance (ANOVA). The level of statistical significance was set at $* \mathrm{P}<0.05$, $* * \mathrm{P}<0.01$ and $* * * \mathrm{P}<0.001$.

\section{Results}

Transplantation of hearts after LCMV infection led to CD8+ T cell exhaustion and persistent viral infection

We analyzed how transfer of viral infected hearts influenced immune activation, viral control and syngeneic graft survival. Therefore, we generated lymphocytic choriomeningitis 


\section{Cellular Physiology Cell Physiol Biochem 2016;38:1171-1181 \\ \begin{tabular}{l|l} 
and Biochemistry Published online: March 11, 2016 & $\begin{array}{l}\text { C } 2016 \text { The Author(s). Published by S. Karger AG, Basel } \\
\text { www.karger.com/cpb }\end{array}$
\end{tabular} \\ Gassa et al.: Donor Derived Viral Infection During Murine Heart Transplantation Induces T Cell Exhaustion}

virus (LCMV) carrier mice by infecting $\mathrm{Tcrb}^{-/-}$mice with $2 \times 10^{6} \mathrm{PFU}$ of LCMV-WE intravenously. LCMV persisted in $\mathrm{Tcrb}^{-/-}$mice (data not shown). 10 to 40 days after infection, we transplanted LCMV loaded hearts from LCMV carrier mice into C57BL/6 mice (WT). Furthermore, we transplanted naïve hearts in WT mice and infected these mice 15 days post-transplant with 200 PFU of LCMV-WE intravenously (Fig. 1A). Transplanted mice, which were infected intravenously with LCMV, could clear the infection, whereas WT recipients receiving LCMV infected hearts could not control the transmitted viral infection (Fig. 1B). Lack of viral control correlated with reduced numbers of LCMV specific CD8 ${ }^{+} \mathrm{T}$ cells (TET$\mathrm{GP}^{+} 3^{+}$) in mice receiving LCMV infected hearts (Fig. 1C). IFN- $\gamma$ production of CD8 ${ }^{+} \mathrm{T}$ cells was reduced on day 14 post-transplant in mice which received LCMV carrier heart transplantation (LCMV-HTX) (Fig. 1D). Transplanted mice showed a transient reduction in the heart function assuming inflammation (Fig. 1E). Indeed, creatinine kinase of muscle-brain type (CK-MB) was enhanced at day 9 post-transplant (Fig. 1F). CK-MB is specific for myocardium and is used as major indicator for myocardial damage besides troponine I (Trop I) \& T. Trop I was mildly elevated but it was not significant (Fig. 1F). Histology revealed mild infiltration of lymphocytes in LCMV infected hearts (Fig. 1G). Taken together, these data show that viral infected hearts activate virus specific $\mathrm{CD} 8^{+} \mathrm{T}$ cells, but with limited functionality resulting in viral persistence and survival of syngeneic heart grafts.

Presence of memory CD8+ T cells led to viral control but acute heart rejection after transplantation of LCMV infected hearts

Next, we investigated whether memory $\mathrm{T}$ cells could prevent viral persistence. Therefore, we induced memory CD8 ${ }^{+} \mathrm{T}$ cells in C57BL/ 6 mice by injecting 200 PFU of LCMVWE intravenously. After priming with LCMV, mice generated a specific immune response which led to control of virus infection [21]. We transplanted LCMV carrier hearts into those memory mice (Fig. 2A). Transplantation of LCMV infected hearts led to massive CD8 ${ }^{+} \mathrm{T}$ cell expansion (Fig. 2B). Memory CD8 ${ }^{+} \mathrm{T}$ cells got highly activated shown by down regulation of CD127, CD62L and PD-1 and high expression of CD44 on GP33 specific CD8 ${ }^{+} \mathrm{T}$ cells (Fig. 2C). Virus specific CD8 ${ }^{+} \mathrm{T}$ cells could control LCMV (Fig. 2D) and transplanted hearts were rejected significantly earlier in memory mice (Fig. 2E). In line with the acute heart rejection, heart specific parameters such as CK-MB and Trop I increased early after transplantation (Fig. 2F). Histology revealed high numbers of infiltrating $\mathrm{CD}^{+} \mathrm{T}$ cells in the transplant (Fig. $1 \mathrm{G})$. In conclusion we found, that presence of memory $\mathrm{CD}^{+} \mathrm{T}$ cells resulted in early virus control, but led to fast rejection of viral infected hearts due to immunopathology.

Transplantation of LCMV infected hearts in absence of Interleukin-10 prevented T cell exhaustion and led to early death of mice

Next, we analyzed possible mechanism of $\mathrm{CD}^{+} \mathrm{T}$ cell exhaustion during transplantation of LCMV infected hearts. Interleukin-10 is known to play a crucial role for $\mathrm{CD}^{+} \mathrm{T}$ cell exhaustion during chronic infection [22]. Infection of LCMV-WE intravenously in $I L-10^{\%}$ mice led to accelerated and increased generation of LCMV specific CD8 ${ }^{+} \mathrm{T}$ cells compared to WT mice (Fig. 3A).Transplantation of carrier hearts into $\mathrm{IL}-10^{\circ}$ mice (Fig. 3B) resulted in higher amounts of CD8 ${ }^{+} \mathrm{T}$ cells (data not shown). Indeed, $I L-10$ was elevated in WT mice receiving LCMV infected heart transplant (Fig. 3C). Virus load in blood was not affected by $I L-10$ (Fig. 3D). $I L-10 \%$ mice rejected the hearts within 10 days (Fig. 3E) and heart enzymes were elevated in $\mathrm{IL-10^{-/ }}$ mice (Fig. 3F). In addition, $\mathrm{IL}_{-10^{-/}}$mice recipients became ill and revealed high levels of lactate dehydrogenase (LDH) and alanine transferase (ALT) indicating a massive cell death in tissue and liver damage (Fig. 3G). Mice revealed systemic illness and died between day 8 and 10 due to immunopathology (Fig. 3H). Together these data show that $I L-10$ was essential to prevent syngeneic graft rejection after transplantation of infected hearts. 
Fig. 1. Transplantation of hearts after LCMV infection led to $\mathrm{CD}^{+} \mathrm{T}$ cell exhaustion and persistent viral infection. (A) Layout showing experimental design of heart transplantation (HTX). In upper panel, naïve C57BL/6 (WT) mice receiving heart from naïve $\mathrm{C} 57 \mathrm{BL} / 6$ mice were infected 15 days post-transplant with $200 \mathrm{PFU}$ of LCMV-WE in travenously. In lower panel, naïve $\mathrm{C} 57 \mathrm{BL} / 6$ (WT) mice receiving LCMV infected carrier hearts from infected $\mathrm{Tcrb}^{-}$mice are shown. Blood analysis were

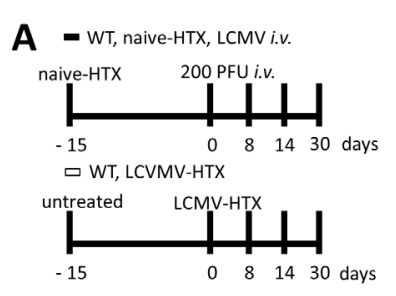

D

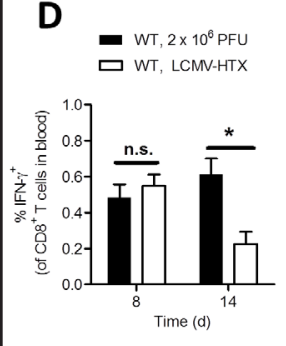

E

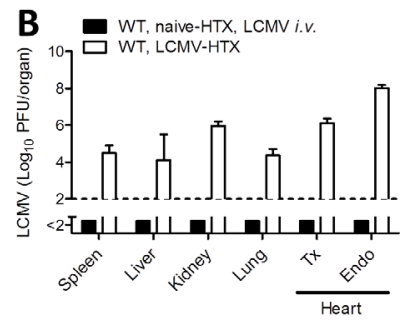

- $\mathbf{F}$ * WT, naive-HTX, L
ET, LCNV-HTX

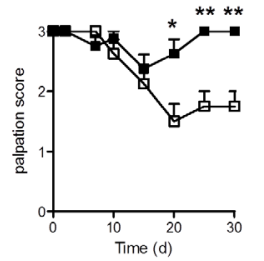

F G WT, LCWN-HTX

G
$H \& E$

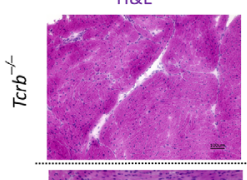

LCMV

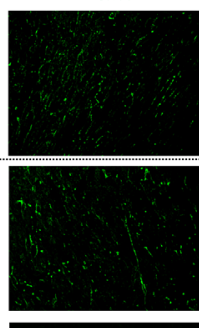

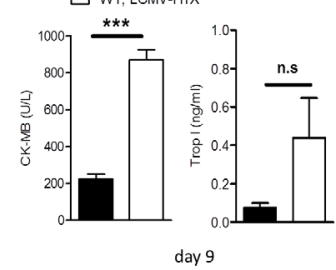

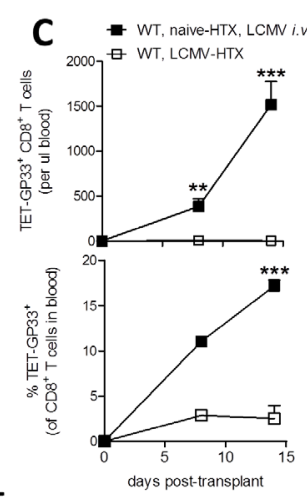

made at indicated days post-transplant. (B) At day 30 post-transplant and post-infection, spleen, liver, kidney, lung, transplanted (Tx) and endogenous (Endo) hearts were analyzed for viral titers ( $\mathrm{n}=4)$. (C) Graph showing frequency of $\mathrm{T}$ cells that were positive for the MHC class I tetramer of the glycoprotein of LCMV (TET-GP33 $)$ and for CD8 $\left(\mathrm{CD}^{+}\right)$in blood from both mice groups as described in (A) ( $\left.\mathrm{n}=4\right)$. (D) Frequency of IFN- $\gamma^{+} \mathrm{CD} 8^{+} \mathrm{T}$ cells in blood is shown after in vitro stimulation with LCMV GP33 peptide for 5 hours. Data shown from blood of naïve WT mice, which were infected with $2 \times 10^{6} \mathrm{PFU}$ of LCMV-WE intravenously (black filled rectangles) and WT mice received LCMV infected hearts (empty rectangles) at indicated days ( $\mathrm{n}=4)$. (E) Abdominal palpation of heart transplant is assessed by palpation scoring. Average palpation score is shown weekly after transplantation and infection $(n=4)$. (F) Levels of CK-MB and Trop I in sera of WT mice infected with $2 \times 10^{6} \mathrm{PFU}$ of LCMV-WE intravenously and in sera of WT mice which received LCMV infected hearts at day 9 post-infection and post-transplant respectively $(n=4)$. (G) Representative H\&E staining of hearts and representative immunofluorescence of hearts stained for LCMV nucleoprotein (green) and CD8 ${ }^{+}$ $\mathrm{T}$ cells (red) are shown. First row shows one representative slide of heart harvested from $\mathrm{Tcrb}^{-/}$mice 30 days post-infection with $2 \times 10^{6} \mathrm{PFU}$ of LCMV-WE. Next three rows show transplanted LCMV infected Tcrb ${ }^{\%}$ hearts in WT mice, memory mice or $I L-10 \%$ mice. Transplanted hearts were harvested when hearts stopped beating. In $I L-10^{-1}$ mice, hearts were harvested between day 8 and $10(\mathrm{n}=7$; pooled from two experiments), in memory mice between day 6 and $8(n=4)$. In case of WT mice, transplanted hearts did not stop beating and were harvested at day 30 post-transplant. Scale bar, $100 \mu \mathrm{m}$ and $50 \mu \mathrm{m}$. Data are shown as mean \pm SEM. ${ }^{*} P<0.05 ;{ }^{* *} P<0.01$ and ${ }^{* * *} P<0.001$ (Student's $t$-test).

\section{KARGER}


A $-\mathrm{WT}$, LCMV-HTX

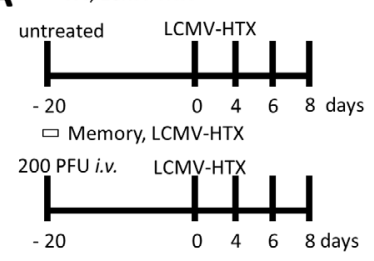

D

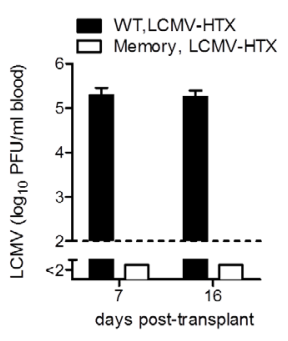

E
B $\quad$ WT, LCMV-HTX
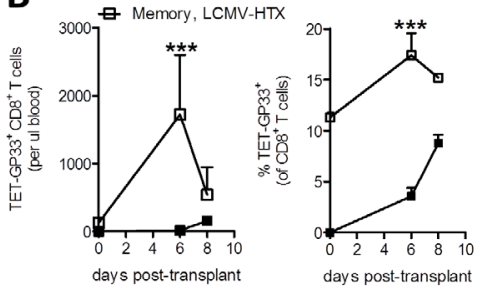
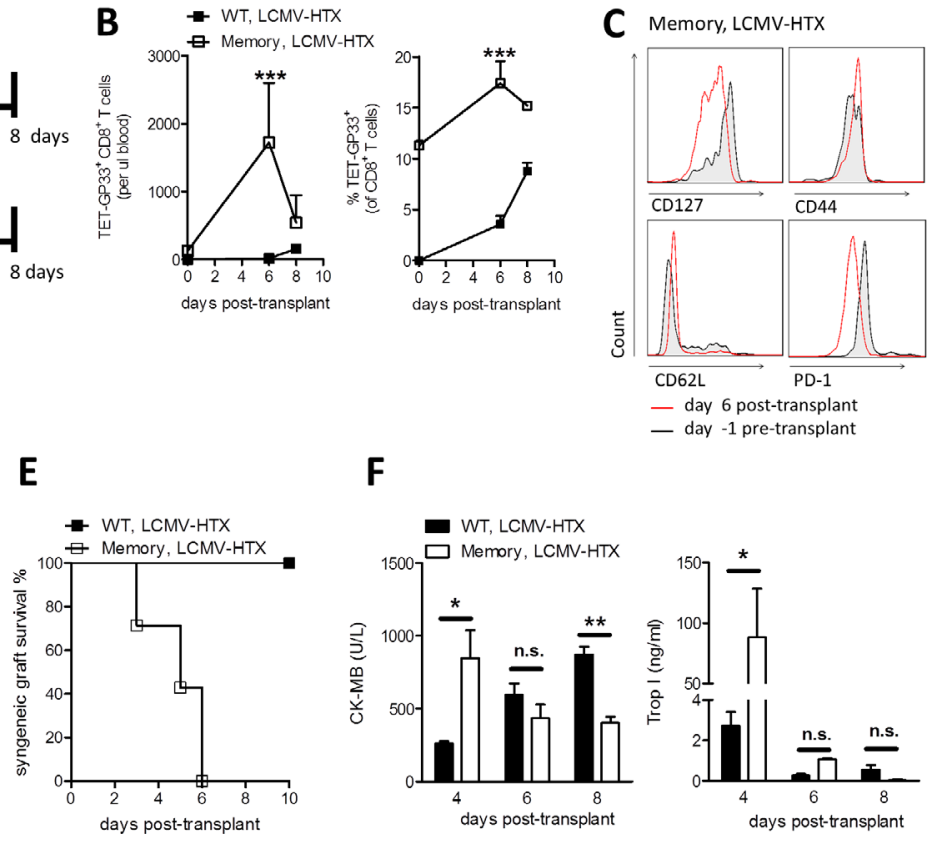

$\mathbf{F}$
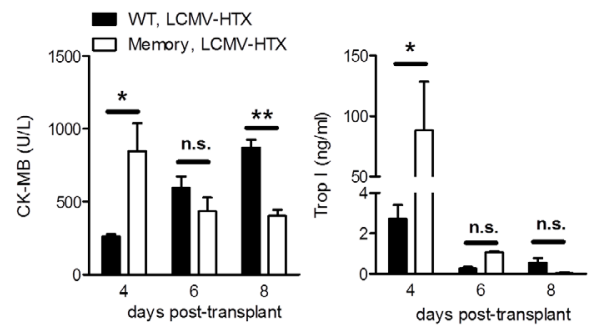

Fig. 2. Presence of memory $\mathrm{CD} 8^{+} \mathrm{T}$ cells led to viral control but acute heart rejection after transplantation of LCMV infected hearts. (A) Layout showing experimental design. Naïve C57BL/6 (WT) mice were infected at least 20 days before HTX with 200 PFU of LCMV-WE intravenously to generate memory mice. Memory mice or naïve C57BL/6 (WT) mice received LCMV infected hearts and blood analysis were made at indicated time points post-transplant. (B) Graph showing frequency of T cells that were positive for the MHC class I tetramer of the glycoprotein of LCMV (TET-GP33 $)$ and for CD8 (CD8 $\left.{ }^{+}\right)$in blood of WT or memory recipients receiving LCMV loaded hearts shown in days post-transplant $(\mathrm{n}=3-5)$. (C) Histogram showing the activation markers CD127, CD62L, CD44 and PD-1 on virus specific TET-GP33 ${ }^{+}$CD8 ${ }^{+} \mathrm{T}$ cells in blood from memory mice before 1 day (black line) and after 6 days of LCMV infected heart transplantation (red line). One histogram blot is shown as a representative of each group $(n=3-5)$. (D) Viral titers are shown in blood at indicated time points $(n=4)$. (E) Syngeneic graft survival is shown in percentage and is determined by stopped heart beating assessed by abdominal palpation (pooled from two experiments; $n=4-7$ ). (F) Graph showing the levels of CK-MB and Trop I post-transplant. $(\mathrm{n}=3-4)$. Data are shown as mean \pm SEM. ${ }^{*} P<0.05 ;{ }^{* *} P<0.01$ and ${ }^{* * *} P<0.001$ (Student's $t$-test).

\section{Discussion}

We mimicked the clinical situation of donor-derived viral infection in SOT in form of heterotopic syngeneic heart transplantation in a mouse model. This system allows us to focus on recipients' immune response against viral infection transmitted through organ transplantation. Still limitation of this model is the lack of mimicking fully or partially MHC mismatch in clinical situation.

Clinically, CMV is a major problem in SOT [23]. CMV is a herpesvirus which is widely spread in human beings. Seroprevalence of CMV varies between 30 and $97 \%$ in population $[24,25]$. Consequently, more than $50 \%$ of solid organ transplant recipients suffer from CMV infection in the first 3 months post-transplant. Seropositivity of donor and recipient play a crucial role in morbidity and mortality for transplant recipient. CMV-seropositive donors and recipients are designated as $\mathrm{D}^{+}$and $\mathrm{R}^{+}$respectively. Subject to seroprevalence, different risk groups are categorized; for $\mathrm{D}^{+}$and $\mathrm{R}^{-}\left(\mathrm{D}^{+} / \mathrm{R}^{-}\right)$matching is the highest risk for CMV disease. The lowest risk for CMV disease is in case of seronegativity in donor and recipient ( $\left.D^{-} / R^{-}\right)$[26]. A CMV prophylaxis treatment is preserved for transplant recipients who are at highest risk for 

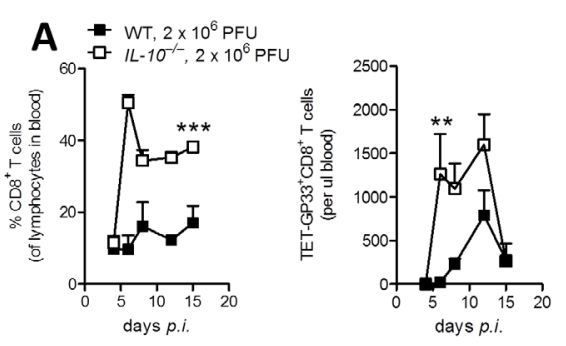

B
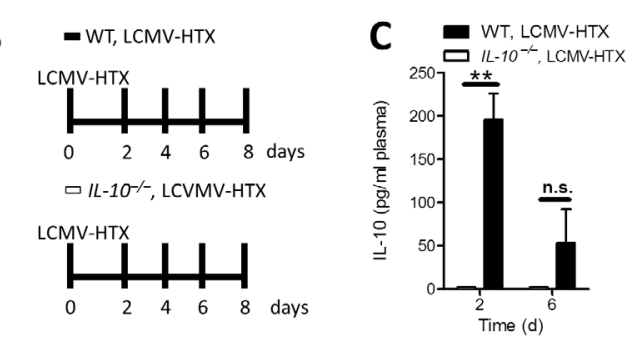

D

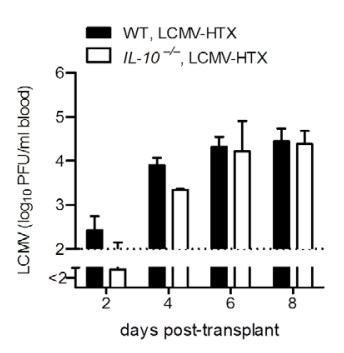

E
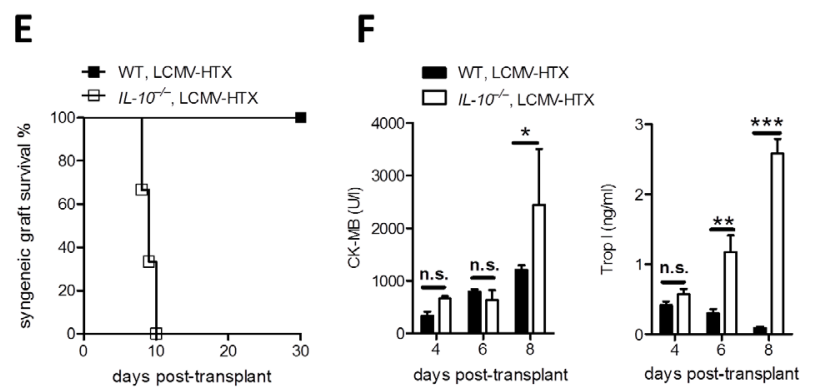

H
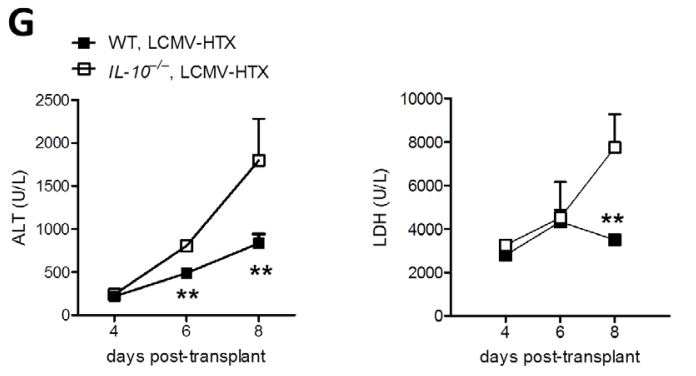

Fig. 3. Transplantation of LCMV infected hearts in the absence of Interleukin-10 prevented T cell exhaustion and led to early death of mice. (A) Naïve $I L-10 \%$ mice and littermate control C57BL/6 mice (WT) were infected with $2 \times 10^{6} \mathrm{PFU}$ of LCMV-WE. Percentage of CD8 ${ }^{+} \mathrm{T}$ cells and total number of TET-GP33 ${ }^{+} \mathrm{CD}^{+} \mathrm{T}$ cells in blood was determined at indicated time points in days post-infection $(\mathrm{n}=3-4)$. (B) Layout showing experimental design. C57BL/6 (WT) mice and $I L-10 \%$ mice receiving LCMV infected carrier hearts and blood analysis were made at indicated days post-transplant. (C) Secretion of $I L$-10 in plasma of transplanted mice has been detected at different time points post-transplant $(n=2-4)$. (D) Viral titers in blood were analyzed at indicated time points $(n=2-4)$. (E) Syngeneic graft survival is shown in percentage and is determined by stopped heart beating assessed by abdominal palpation ( $n=3-5)$. (F) Sera of recipients have been analyzed for heart specific enzymes such as CK-MB and Trop I at several time points $(n=2-4)$. (G) Sera were analyzed for the enzymes ALT and LDH at indicated days post-transplant $(n=2-4)$. $(\mathrm{H})$ Graph showing survival of C57BL/6 mice (WT) and $I L-10 \%$ mice received LCMV carrier heart (n=7-15). Data are pooled from 2 or 3 independent experiments. Data are shown as mean \pm SEM. ${ }^{*} P<0.05$; ${ }^{* *} P<0.01$ and ${ }^{* * *} P<0.001$ (Student's $t$-test).

CMV disease $\left(\left(\mathrm{D}^{+} / \mathrm{R}^{-}\right)\right.$and $\left.\left(\mathrm{D}^{+} / \mathrm{R}^{+}\right)\right)$. A retrospective study compared morbidity and mortality in four CMV donor/recipient serostatus categories [27]. As result, the group $\mathrm{D}^{+} / \mathrm{R}^{+}$showed the highest risk for mortality post-transplant, even though CMV disease occurs more often in $\mathrm{D}^{+} / \mathrm{R}^{-}$. In line with our data, recipients with memory $\mathrm{T}$ cells against the graft-transmitted virus show a strong immune response against syngeneic graft leading to rejection, whereas LCMV infection via transplant in naïve recipient mice led to chronic viral infection due to $\mathrm{CD}^{+} \mathrm{T}$ cell exhaustion. The grafts survived and showed only partial dysfunction. 
Another example for donor-derived infection is LCMV. LCMV is an arenavirus, which is very rare in human beings. An infection is usually asymptomatic in healthy persons and can be caused after close contact to house mice or hamsters $[28,29]$. Some cases are known where LCMV was transmitted during transplantation. Donor-derived infection in several recipients led to death within three weeks after transplantation. The same strain could be detected in a cluster of patients, where seven of eight recipients died. The recipients revealed unspecific symptoms such as diarrhea, fever and systemic illness [30]. Normally, LCMV infection in non-immunosuppressed humans is asymptomatic.

Immunosuppression after transplantation aims to reduce immune response by the adaptive immune system. Nevertheless, it encloses many side effects such as a higher risk of opportunistic infections, an increased incidence of cancer and toxicity [31].

A new perspective for tolerance in SOT is to understand CD8 ${ }^{+} \mathrm{T}$ cell exhaustion. T cell exhaustion is defined as a loss of effector function [32,33]. Gradual loss can be distinguished in stages which are determined by diminished or vanished production of effector cytokines such as IFN- $\gamma$, increased expression of inhibitory cytokine receptors and deletion of antigenspecific T cells. Plus, T cell exhaustion correlates with viral persistence. Little is known in the field of transplantation medicine. We know that $\mathrm{T}$ cell exhaustion limits the immune response against chronic infections and tumors. In case of recrudescence of exhausted $\mathrm{T}$ cells, clearance of infections and tumors can be induced [34].

Previous clinical studies effort to reactivate exhausted T cells as treatment for chronic infections or tumor disease [35]. However, the mechanisms leading to $\mathrm{T}$ cell exhaustion are unknown. Further, the role of $\mathrm{T}$ cell exhaustion in transplantation or autoimmunity is not defined. Recently, Sarraj et al. [36] showed that genetic depletion of selectin ligand for leucocyte migration led to impaired T cell function. They focused on $\mathrm{CD} 4^{+} \mathrm{T}$ cells and induced $\mathrm{T}$ cell exhaustion in a murine transplantation model by impaired migration capability. They determined $\mathrm{T}$ cell exhaustion by impaired effector cytokine production (IFN- $\gamma$ ), defective proliferation of $\mathrm{CD}^{+} \mathrm{T}$ cells and higher PD-1 expression. Knock-out mice recipients providing impaired migration capability revealed $\mathrm{T}$ cell exhaustion and showed prolonged graft survival. T cells were not able to migrate in the MHC II mismatched heart transplant which in consequence led to permanent activation of $\mathrm{T}$ cells and then to $\mathrm{T}$ cell exhaustion. Graft survival was significantly increased. The data demonstrate that $\mathrm{T}$ cell exhaustion can lead to tolerance of syngeneic graft.

In line with that finding, $I L-10$ is an immunoregulatory cytokine that is associated with $\mathrm{T}$ cell exhaustion [37]. Its function during viral infection is described to be immunosuppressive by suppressing cytokine production and proliferation of $\mathrm{CD}^{+}$and $\mathrm{CD} 4^{+} \mathrm{T}$ cells leading to viral persistence [38]. A variety of cells can produce $I L-10$ such as T cells, B cells and antigenpresenting cells (APC) $[37,39,40]$. Clinical studies demonstrated that polymorphisms linked with increased $I L-10$ production are associated with increased susceptibility to chronic HCV infection and increased severity of chronic HBV infection [41-43]. Vice versa, polymorphisms with reduced expression of $I L-10$ correlate with a slower progression of AIDS in HIV- infected patients [44]. Its role in transplantation medicine is poorly understood. As $I L-10$ is known for its anti-inflammatory response and immunosuppressive role, it should abet graft survival.

Indeed, $I L-10$ inhibits ischemia/reperfusion injury [45], extends syngeneic graft survival and function [46-48] and is essential for the action of regulatory $\mathrm{T}$ cells mediating tolerance at least in some transplant models [49]. In our model, $I L-10$ deficiency mice receiving LCMV loaded heart died early after transplantation. Loss of $I L-10$ in recipients showed a systemic immune response with immunopathology indicating that absence of $I L$ 10 prevents $\mathrm{T}$ cell exhaustion. Its immunoregulatory function during viral infection through organ transplantation helps tolerating the syngeneic graft. In addition $I L-10$ may impact on regulatory cells, which can influence heart function [50]. This changed in case of memory mice. Memory CD8 ${ }^{+} \mathrm{T}$ cells were capable to control donor-derived LCMV infection but induced an acute graft rejection. Memory T cells play a major role in acute and chronic syngeneic graft rejection. Pre-transplant frequency of donor-specific alloreactive memory $\mathrm{T}$ cells in recipient correlates with the risk of long-term graft rejection [51]. Previous experimental 


\section{Cellular Physiology Cell Physiol Biochem 2016;38:1171-1181 \\ \begin{tabular}{l|l} 
and Biochemistry Published online: March 11, 2016 & $\begin{array}{l}\text { DO 2016 The Author(s). Published by S. Karger AG, Basel } \\
\text { www.karger.com/cpb }\end{array}$
\end{tabular} \\ Gassa et al.: Donor Derived Viral Infection During Murine Heart Transplantation Induces \\ T Cell Exhaustion}

models demonstrate their potential alloreactivity. They even showed that cross-reactivity could lead to alloreaction defined as heterologous immunity [52]. In our case replication competent LCMV in heart transplant was rejected in memory mice. These facts emphasize the significance of donor-derived viral infection. While we focused here on the role of $I L-10$, several other pathways are activated during virus infection which similarly might influence outcome of heart transplantation [53-55].

In summary immunized patients exposed to viral load facing possible alloreaction have to be treated virus specifically. $I L-10$ therapy in case of unexpected donor-derived viral infection could be a potential immunotherapy to prevent viral infection induced graft rejection.

\section{Acknowledgments}

We thank Konstanze Schättel, Anna Höwner and Patricia Spieker for technical support. This study was funded by the Sofja Kovalevskaja Award from the Alexander von Humboldt Foundation (SKP2008 and SKP2010) and Deutsche Forschungsgemeinschaft DFG LA1419/51 and LA2558/5-1. This study was further supported by the Sonderforschungsbereich SFB974 and Transregio TRR60. This work was also supported by the Canadian Institutes of Health Research grant to NB.

\section{Disclosure Statement}

The authors of this manuscript have no conflicts of interest to disclose as described by the journal of Cellular Physiology and Biochemistry.

\section{References}

1 Hoffman FM: Outcomes and complications after heart transplantation: A review. J Cardiovasc Nurs 2005;20:S31-42.

2 Hunt SA, Haddad F: The changing face of heart transplantation. J Am Coll Cardiol 2008;52:587-598.

3 Trulock EP, Christie JD, Edwards LB, Boucek MM, Aurora P, Taylor DO, Dobbels F, Rahmel A0, Keck BM, Hertz MI: Registry of the international society for heart and lung transplantation: Twenty-fourth official adult lung and heart-lung transplantation report-2007. J Heart Lung Transplant 2007;26:782-795.

4 Jung SH, Kim JJ, Choo SJ, Yun TJ, Chung CH, Lee JW: Long-term mortality in adult orthotopic heart transplant recipients. J Korean Med Sci 2011;26:599-603.

5 Taylor DO, Edwards LB, Aurora P, Christie JD, Dobbels F, Kirk R, Rahmel AO, Kucheryavaya AY, Hertz MI: Registry of the international society for heart and lung transplantation: Twenty-fifth official adult heart transplant report--2008. J Heart Lung Transplant 2008;27:943-956.

6 Grossi PA, Fishman JA, Practice ASTIDCo: Donor-derived infections in solid organ transplant recipients. Am J Transplant 2009;9:S19-26.

7 Razonable RR: Management of viral infections in solid organ transplant recipients. Expert Rev Anti Infect Ther 2011;9:685-700.

8 Winston DJ, Vikram HR, Rabe IB, Dhillon G, Mulligan D, Hong JC, Busuttil RW, Nowicki MJ, Mone T, Civen R, Tecle SA, Trivedi KK, Hocevar SN, West Nile Virus Transplant-Associated Transmission Investigation T: Donor-derived west nile virus infection in solid organ transplant recipients: Report of four additional cases and review of clinical, diagnostic, and therapeutic features. Transplantation 2014;97:881-889.

9 Srinivasan A, Burton EC, Kuehnert MJ, Rupprecht C, Sutker WL, Ksiazek TG, Paddock CD, Guarner J, Shieh WJ, Goldsmith C, Hanlon CA, Zoretic J, Fischbach B, Niezgoda M, El-Feky WH, Orciari L, Sanchez EQ Likos A, Klintmalm GB, Cardo D, LeDuc J, Chamberland ME, Jernigan DB, Zaki SR, Rabies in Transplant Recipients Investigation T: Transmission of rabies virus from an organ donor to four transplant recipients. N Engl J Med 2005;352:1103-1111.

10 Ison MG, Nalesnik MA: An update on donor-derived disease transmission in organ transplantation. Am J Transplant 2011;11:1123-1130.

11 Fishman JA, Strong DM, Kuehnert MJ: Organ and tissue safety workshop 2007: Advances and challenges. Cell Tissue Bank 2009;10:271-280. 
12 Fishman JA: Infection in solid-organ transplant recipients. N Engl J Med 2007;357:2601-2614.

13 Valujskikh A, Li XC: Memory t cells and their exhaustive differentiation in allograft tolerance and rejection. Curr Opin Organ Transplant 2012;17:15-19.

14 Corry RJ, Winn HJ, Russell PS: Heart transplantation in congenic strains of mice. Transplant Proc 1973;5:733-735.

15 Wu K, Zhang J, Fu J, Wu S, Philipp T, Uwe H, Kribben A, Witzke O: Novel technique for blood circuit reconstruction in mouse heart transplantation model. Microsurgery 2006;26:594-598.

16 Nagano H, Mitchell RN, Taylor MK, Hasegawa S, Tilney NL, Libby P: Interferon-gamma deficiency prevents coronary arteriosclerosis but not myocardial rejection in transplanted mouse hearts. J Clin Invest 1997;100:550-557.

17 Funabashi H, Uchida K, Kado S, Matsuoka Y, Ohwaki M: Establishment of a tcrb and trp53 genes deficient mouse strain as an animal model for spontaneous colorectal cancer. Exp Anim 2001;50:41-47.

18 Hunziker L, Recher M, Macpherson AJ, Ciurea A, Freigang S, Hengartner H, Zinkernagel RM: Hypergammaglobulinemia and autoantibody induction mechanisms in viral infections. Nat Immunol 2003;4:343-349.

19 Kuhn R, Lohler J, Rennick D, Rajewsky K, Muller W: Interleukin-10-deficient mice develop chronic enterocolitis. Cell 1993;75:263-274.

20 Lang PA, Contaldo C, Georgiev P, El-Badry AM, Recher M, Kurrer M, Cervantes-Barragan L, Ludewig B, Calzascia T, Bolinger B, Merkler D, Odermatt B, Bader M, Graf R, Clavien PA, Hegazy AN, Lohning M, Harris NL, Ohashi PS, Hengartner H, Zinkernagel RM, Lang KS: Aggravation of viral hepatitis by platelet-derived serotonin. Nat Med 2008;14:756-761.

21 Duhan V, Khairnar V, Friedrich SK, Zhou F, Gassa A, Honke N, Shaabani N, Gailus N, Botezatu L, Khandanpour C, Dittmer U, Haussinger D, Recher M, Hardt C, Lang PA, Lang KS: Virus-specific antibodies allow viral replication in the marginal zone, thereby promoting cd8(+) t-cell priming and viral control. Sci Rep 2016;6:19191.

22 Brooks DG, Trifilo MJ, Edelmann KH, Teyton L, McGavern DB, Oldstone MB: Interleukin-10 determines viral clearance or persistence in vivo. Nat Med 2006;12:1301-1309.

23 Razonable RR, Humar A, Practice ASTIDCo: Cytomegalovirus in solid organ transplantation. Am J Transplant 2013;13:93-106.

24 Cannon MJ, Schmid DS, Hyde TB: Review of cytomegalovirus seroprevalence and demographic characteristics associated with infection. Rev Med Virol 2010;20:202-213.

25 Bate SL, Dollard SC, Cannon MJ: Cytomegalovirus seroprevalence in the united states: The national health and nutrition examination surveys, 1988-2004. Clin Infect Dis 2010;50:1439-1447.

26 Ramanan P, Razonable RR: Cytomegalovirus infections in solid organ transplantation: A review. Infect Chemother 2013;45:260-271.

27 Harvala H, Stewart C, Muller K, Burns S, Marson L, MacGilchrist A, Johannessen I: High risk of cytomegalovirus infection following solid organ transplantation despite prophylactic therapy. J Med Virol 2013;85:893-898.

28 Childs JE, Glass GE, Korch GW, Ksiazek TG, Leduc JW: Lymphocytic choriomeningitis virus infection and house mouse (mus musculus) distribution in urban baltimore. Am J Trop Med Hyg 1992;47:27-34.

29 Childs JE, Glass GE, Ksiazek TG, Rossi CA, Oro JG, Leduc JW: Human-rodent contact and infection with lymphocytic choriomeningitis and seoul viruses in an inner-city population. Am J Trop Med Hyg 1991;44:117-121.

30 Fischer SA, Graham MB, Kuehnert MJ, Kotton CN, Srinivasan A, Marty FM, Comer JA, Guarner J, Paddock CD, DeMeo DL, Shieh WJ, Erickson BR, Bandy U, DeMaria A, Jr., Davis JP, Delmonico FL, Pavlin B, Likos A, Vincent MJ, Sealy TK, Goldsmith CS, Jernigan DB, Rollin PE, Packard MM, Patel M, Rowland C, Helfand RF, Nichol ST, Fishman JA, Ksiazek T, Zaki SR, Team LiTRI: Transmission of lymphocytic choriomeningitis virus by organ transplantation. N Engl J Med 2006;354:2235-2249.

31 Halloran PF: Immunosuppressive drugs for kidney transplantation. N Engl J Med 2004;351:2715-2729.

32 Wherry EJ: T cell exhaustion. Nat Immunol 2011;12:492-499.

33 Yi JS, Cox MA, Zajac AJ: T-cell exhaustion: Characteristics, causes and conversion. Immunology 2010;129:474-481.

34 Blank C, Mackensen A: Contribution of the pd-11/pd-1 pathway to t-cell exhaustion: An update on implications for chronic infections and tumor evasion. Cancer Immunol Immunother 2007;56:739-745.

35 Sharpe M, Mount N: Genetically modified t cells in cancer therapy: Opportunities and challenges. Dis Model Mech 2015;8:337-350. 
36 Sarraj B, Ye J, Akl AI, Chen G, Wang JJ, Zhang Z, Abadja F, Abecassis M, Miller SD, Kansas GS, Ansari MJ: Impaired selectin-dependent leukocyte recruitment induces t-cell exhaustion and prevents chronic allograft vasculopathy and rejection. Proc Natl Acad Sci USA 2014;111:12145-12150.

37 Blackburn SD, Wherry EJ: Il-10, t cell exhaustion and viral persistence. Trends Microbiol 2007;15:143-146.

38 Lang PA, Recher M, Haussinger D, Lang KS: Genes determining the course of virus persistence in the liver: Lessons from murine infection with lymphocytic choriomeningitis virus. Cell Physiol Biochem 2010;26:263-272.

39 Moore KW, de Waal Malefyt R, Coffman RL, O'Garra A: Interleukin-10 and the interleukin-10 receptor. Annu Rev Immunol 2001;19:683-765.

40 Seiffart V, Zoeller J, Klopfleisch R, Wadwa M, Hansen W, Buer J, Riedel C, Westendorf AM: Il10-deficiency in $\mathrm{cd}^{+} \mathrm{t}$ cells exacerbates the ifngamma and il17 response during bacteria induced colitis. Cell Physiol Biochem 2015;36:1259-1273.

41 Persico M, Capasso M, Persico E, Masarone M, Renzo A, Spano D, Bruno S, Iolascon A: Interleukin-10 - 1082 gg polymorphism influences the occurrence and the clinical characteristics of hepatitis c virus infection. J Hepatol 2006;45:779-785.

42 Paladino N, Fainboim H, Theiler G, Schroder T, Munoz AE, Flores AC, Galdame O, Fainboim L: Gender susceptibility to chronic hepatitis c virus infection associated with interleukin 10 promoter polymorphism. J Virol 2006;80:9144-9150.

43 Knapp S, Hennig BJ, Frodsham AJ, Zhang L, Hellier S, Wright M, Goldin R, Hill AV, Thomas HC, Thursz MR: Interleukin-10 promoter polymorphisms and the outcome of hepatitis c virus infection. Immunogenetics 2003;55:362-369.

44 Shin HD, Winkler C, Stephens JC, Bream J, Young H, Goedert JJ, O'Brien TR, Vlahov D, Buchbinder S, Giorgi J, Rinaldo C, Donfield S, Willoughby A, O'Brien SJ, Smith MW: Genetic restriction of hiv-1 pathogenesis to aids by promoter alleles of il10. Proc Natl Acad Sci USA 2000;97:14467-14472.

45 Deng J, Kohda Y, Chiao H, Wang Y, Hu X, Hewitt SM, Miyaji T, McLeroy P, Nibhanupudy B, Li S, Star RA: Interleukin-10 inhibits ischemic and cisplatin-induced acute renal injury. Kidney Int 2001;60:2118-2128.

46 Feng X, Zheng XX, Yi S, Lehnert AM, Strom TB, O'Connell PJ: Il-10/fc inhibits macrophage function and prolongs pancreatic islet xenograft survival. Transplantation 1999;68:1775-1783.

47 Zuo Z, Wang C, Carpenter D, Okada Y, Nicolaidou E, Toyoda M, Trento A, Jordan SC: Prolongation of allograft survival with viral il-10 transfection in a highly histoincompatible model of rat heart allograft rejection. Transplantation 2001;71:686-691.

48 Cypel M, Liu M, Rubacha M, Yeung JC, Hirayama S, Anraku M, Sato M, Medin J, Davidson BL, de Perrot M, Waddell TK, Slutsky AS, Keshavjee S: Functional repair of human donor lungs by il-10 gene therapy. Sci Transl Med 2009;1:4ra9.

49 Hara M, Kingsley CI, Niimi M, Read S, Turvey SE, Bushell AR, Morris PJ, Powrie F, Wood KJ: Il-10 is required for regulatory t cells to mediate tolerance to alloantigens in vivo. J Immunol 2001;166:3789-3796.

50 Tang T-T, Ding Y-J, Liao Y-H, Yu X, Xiao H, Xie J-J, Yuan J, Zhou Z-H, Liao M-Y, Yao R, Cheng Y, Cheng X: Defective circulating cd4cd25+foxp3+cd127(low) regulatory t-cells in patients with chronic heart failure. Cell Physiol Biochem 2010;25:451-458.

51 Heeger PS, Greenspan NS, Kuhlenschmidt S, Dejelo C, Hricik DE, Schulak JA, Tary-Lehmann M: Pretransplant frequency of donor-specific, ifn-gamma-producing lymphocytes is a manifestation of immunologic memory and correlates with the risk of posttransplant rejection episodes. J Immunol 1999;163:2267-2275.

52 van den Heuvel H, Heidt S, Roelen DL, Claas FH: T-cell alloreactivity and transplantation outcome: A budding role for heterologous immunity? Curr Opin Organ Transplant 2015;20:454-460.

53 Shaabani N, Honke N, Lang PA, Gorg B, Proksch P, Gailus N, Gotoh T, Haussinger D, Lang KS: Tunicamycin inhibits diabetes. Cell Physiol Biochem 2012;29:595-602.

54 Merches K, Khairnar V, Knuschke T, Shaabani N, Honke N, Duhan V, Recher M, Navarini AA, Hardt C, Haussinger D, Tummler B, Gulbins E, Futerman AH, Hoffmann D, Lang F, Lang PA, Westendorf AM, Lang KS: Virus-induced type i interferon deteriorates control of systemic pseudomonas aeruginosa infection. Cell Physiol Biochem 2015;36:2379-2392.

55 Badr G, Waly H, Eldien HMS, Abdel-Tawab H, Hassan K, Alhazza IM, Ebaid H, Alwasel SH: Blocking type I interferon (IFN) signaling impairs antigen responsiveness of circulating lymphocytes and alters their homing to lymphoid organs: Protective role of type I IFN. Cell Physiol Biochem 2010;26:1029-1040. 